\title{
Isolation and sequencing of seven Sox genes from the lacertid lizard Eremias breuchleyi
}

\author{
Jie Li, Ping-Ping Zheng, Jiao-Lian Song, Jin-Long Rui and Liu-Wang Nie \\ Life Science College, Anhui Normal University, Wuhu, Anhui province, China
}

\begin{abstract}
The Sox family of genes shares a high sequence similarity with the HMG box region of the human $Y$ chromosomal gene, SRY. We used highly degenerate primers to clone and sequence seven Eremias breuchleyi Sox genes (EbSox2, EbSox3, EbSox4, EbSox11, EbSox12, EbSox14 and EbSox21). A database search for the cloned sequences revealed the following percentage identity with the homologous human SOX genes: EbSox2 = 96\%, $E b S o x 3=88 \%$, EbSox4 =94\%, EbSox11 =99\%, EbSox12=96\%, EbSox14=98\%, EbSox21=97\%. Cluster analysis indicates that they seem to belong to group B and group C of Sox gene family, respectively.
\end{abstract}

Key words: Eremias breuchleyi, PCR, sequence analysis, Sox genes, SSCP.

Received:October 10, 2005; Accepted: December 21, 2005.

The Sox (SRY related HMG-box gene, Sox) genes form a large family which is characterized by a highly conserved DNA-binding and share a high sequence similarity with the HMG (high mobility group, HMG) box region of the human Y chromosomal gene, SRY (Sex-determining region of Y chromosome, SRY) (Hawkins JR, 1994; Pevny LH, 1997). More than 30 Sox genes have been identified in mammals and their orthologues have been found in a wide range of other metazoans (Hagiuda et al., 2003). The Sox genes are highly conserved and are known to play important roles in embryonic development including roles in gonad, central nervous system, neural crest and skeletal development (Nagai, 2001). For instance, mutation in the SOX9 gene has been associated with sex reversal in men (Foster et al., 1994; Wagner et al., 1994), while targeted mutagenesis in mice has shown that Sox4 is essential for heart and lymphocyte development (Schilham et al., 1996). In addition, tissue culture experiments have shown that mouse Sox 1, Sox 2 and Sox 3 genes are expressed mainly in nervous system development and are involved in determining the fate of neuronal cells (Collignon et al., 1996; Pevny et al., 1998; Li et al., 1998). However, the role of these genes in the development and differentiation of reptiles has yet to be explored.

The lacertid lizard, Eremias breuchleyi, lacks identifiable sex chromosomes but it appears that the sex determination in this species might be genetic because incubation temperature does not influence sex development. As a pre-

Send correspondence to Liu-wang Nie. Life Science College, Anhui Normal University, 1 East Beijing Road, wuhu, 241000 Anhui, China. E-mail: Iwnie@mail.ahnu.edu.cn. lude to understanding the involvement of $S R Y$-like genes in the development and differentiation of reptiles, we attempted to clone the Sox genes family of E. breuchleyi using the polymerase chain reaction (PCR). In the present paper we report the cloning and nucleotide sequence of seven E. breuchleyi Sox genes which show extensive homology with the Sox genes of various other vertebrate taxa. The phylogenetic evolution of Sox genes is also discussed.

Two male and two female E. breuchleyi were captured from Qianshan, Suzhou, Anhui province, China and the genomic DNA isolated from muscle tissues using routine protocols (Sambrook et al., 1989). A pair of PCR primers was designed using a multiple alignment of a HMG-box sequence representative of $S R Y / S o x$ gene family, primer 1 being: 5'-AGCGACCCATGAA(CT)GC(AGCT)TT(CT) AT(AGCT)G-3' and primer 2 being: 5'-ACGAGGTCG ATA(CT)TT(AG)TA(AG)T(CT)(AGCT)GG-3'. The amplification fragment length was $216 \mathrm{bp}$ using these primer pairs.

Amplifications were carried out in a total volume of $25 \mu \mathrm{L}$ containing $100 \mathrm{ng}$ of sample genomic DNA, $1.5 \mathrm{mM}$ $\mathrm{Mg}^{2+}, 120 \mu \mathrm{M}$ dNTP, $0.3 \mu \mathrm{M}$ of each primer, 1.25 units of Taq polymerase and $\mathrm{H}_{2} \mathrm{O}$. The $\mathrm{PCR}$ cycling condition were 5 min at $97{ }^{\circ} \mathrm{C}$, followed by 35 cycles of $40 \mathrm{~s}$ at $94{ }^{\circ} \mathrm{C}, 40 \mathrm{~s}$ at $55.5^{\circ} \mathrm{C}$ and $50 \mathrm{~s}$ at $72{ }^{\circ} \mathrm{C}$ with a final $10 \mathrm{~min}$ elongation at $72{ }^{\circ} \mathrm{C}$.

The PCR products were detected on $1.7 \%(\mathrm{w} / \mathrm{v})$ agarose gels and cloned using the pMD 18-T vector (purchased from TaKaRa). 100 white clones were transferred to a plate of clones from initial culture plate and 81 positive clones 
with inserted Sox DNA were confirmed using colony PCR. The distinct positive clones were screened using singlestrand conformation polymorphism (SSCP) analysis method (Nie, Shan and Guo, 1999) and sequenced using the universal sequencing primers on an ABI377 auto-sequencer. DNA sequences were analyzed using the BLAST (http://www.ncbi.nlm.nih.gov/BLAST/) and CLUSTALX programs (http://www.igh.cnrs.fr/bin/clustalxguess.cgi) and a phylogenetic tree was constructed using the Molecular Evolutionary Genetic Analysis (MEGA) software.

We succeeded in cloning a $220 \mathrm{bp}$ fragment using $E$. breuchleyi genomic DNA as template. Seven distinct Soxpositive clones, representing distinct Sox genes, were selected from male and female E. breuchleyi but there was no sexual difference between them (Figure 1a). We named the genes Eremias breuchleyi Sox (EbSox) based on BLAST analysis, the isolated genes being EbSox2 (DQ067423), EbSox3 (DQ067425), EbSox4 (DQ067426), EbSoxl1 (DQ 067427), EbSox12 (DQ067428), EbSox14 (DQ067430), EbSox21 (DQ067433) (sequence accession numbers of GenBank in parentheses). The putative amino acid sequences of these Sox genes are shown in Figure 1b. A database search for the cloned sequences revealed the following percentage identity with the homologous human SOX genes: $E b S o x 2=96 \%, E b S o x 3=88 \%$, EbSox $4=94 \%$, EbSox $11=99 \%$, EbSox $12=96 \%$, EbSox $14=98 \%$, EbSox $21=97 \%$.

The HMG domain sequence RPMNAFMVW (positions 2 10) appears to be conserved for all SOX sequences (Bowles, Schepers and Koopman, 2000). Figure 2a shows the sequence comparison of 72 conserved HMG-box amino acid residues from the 29 Sox genes sequences (Table 1) and the seven sequences cloned by us. Comparison of these 36 HMG domains showed that they were clustered within distinct phylogenetic sub-groups (Figure $2 \mathrm{~b}$ ). The previous studies had showed that all characteristic SOX/Sox genes can be divided into ten groups (A-J) (Bowles, Schepers and Koopman, 2000). In our study we found that the seven $E$. breuchleyi Sox genes did not cluster together but were distributed between the B and C Sox groups. It is known that Sox1, Sox 2 and Sox 3 are members of the family of HMG DNA-binding domain containing transcription factors related to the testis-determination Sry gene and, along with the recently discovered Sox 14 and Sox 21 genes, comprise the group B subfamily of Sox genes (Collignon et al., 1996), while the members of group C (Sox4, Sox11, Sox12, Sox 22 and Sox 24) encode highly conserved N- and C- terminal amino acid sequences (Collignon et al., 1996; Pevny and Lovell-Badge, 1997; Arsic et al., 1998; Rex et al., 1997; Kamachi et al., 1995; Hargrave et al., 2000; Uchikawa et al., 1999). It should be remembered, however, that the PCR primer set used by us may have had a bias leading to preferential amplification of group B and C $E$. breuchleyi Sox genes.

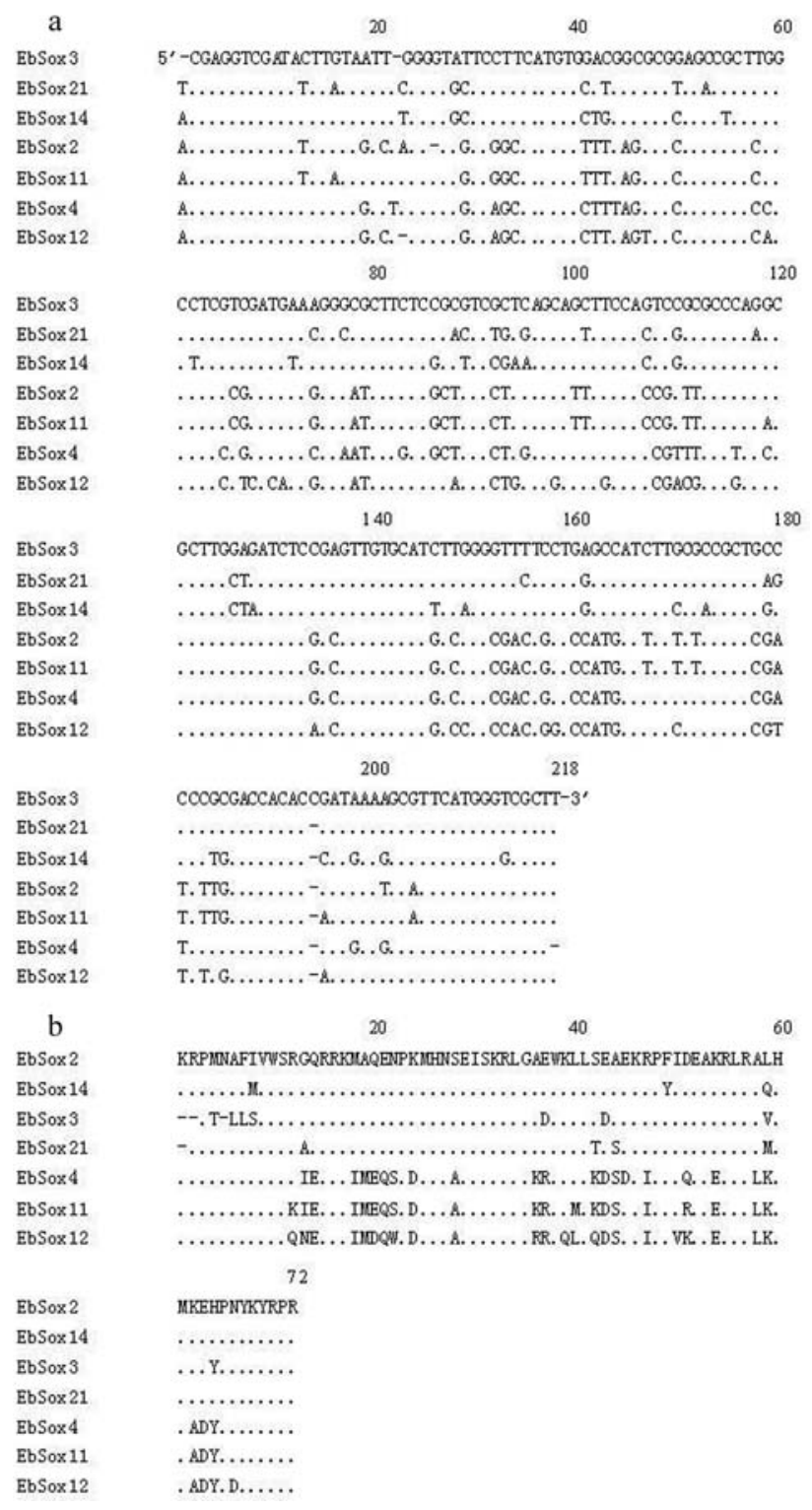

Figure 1 - Sox gene HMG-boxes of Eremias breuchleyi. (a) DNA sequence; dots indicate identities with EbSox3; (b) putative amino acid sequence; dots indicate identities with EbSox2.

The members of the Sox genes family have been highly conserved though evolution and have been found in a wide variety of species. In the Sox3 gene product (Figure 2a), there is a D (Asp) amino acid at position 66 in bird,mouse and human but it is $\mathrm{N}$ (Asn) in E. breuchleyi. At position 20 and 42 the amino acid is identical between human and mouse SOX3 protein but shows a conservative change in other species, while in the rest of the protein the Sox3 gene amino acid sequences are highly conserved. It is probable that gene duplication has caused the diversity seen in the HMG box superfamily in which the Sox family of genes shows the highest mutation rate (Laudet, et al., 1993). In the phylogeny of the Sox family the Sox4 gene is considered to be an early offshoot and the $S R Y$ gene a recent 
a

\begin{tabular}{|c|}
\hline $20 \operatorname{son} 3$ \\
\hline Gallsoz3 \\
\hline Homosox3 \\
\hline Mussous 3 \\
\hline Homosox 2 \\
\hline Massoz 2 \\
\hline Dand Soz2 \\
\hline Gallsoz2 \\
\hline Xenosoz2 \\
\hline EbSou2 2 \\
\hline Homosox14 \\
\hline MusSor 14 \\
\hline Gallsoz14 \\
\hline EbSor14 \\
\hline TakiSoz14 \\
\hline Fomo90X21 \\
\hline MasSor 21 \\
\hline Dani Soz 21 \\
\hline EbSor21 \\
\hline Gallsoz21 \\
\hline XenoSoz3 \\
\hline Homosox 4 \\
\hline n11iSozA \\
\hline Gallsoz4 \\
\hline DaniSoz4 \\
\hline Massor 4 \\
\hline EbSond \\
\hline Homosox11 \\
\hline MusSorz11 \\
\hline Gallsoz11 \\
\hline Dani Soz11 \\
\hline Eb Sout 1 \\
\hline XeroSoz11 \\
\hline HomoSoX12 \\
\hline MusSou 12 \\
\hline EbSon1 2 \\
\hline
\end{tabular}

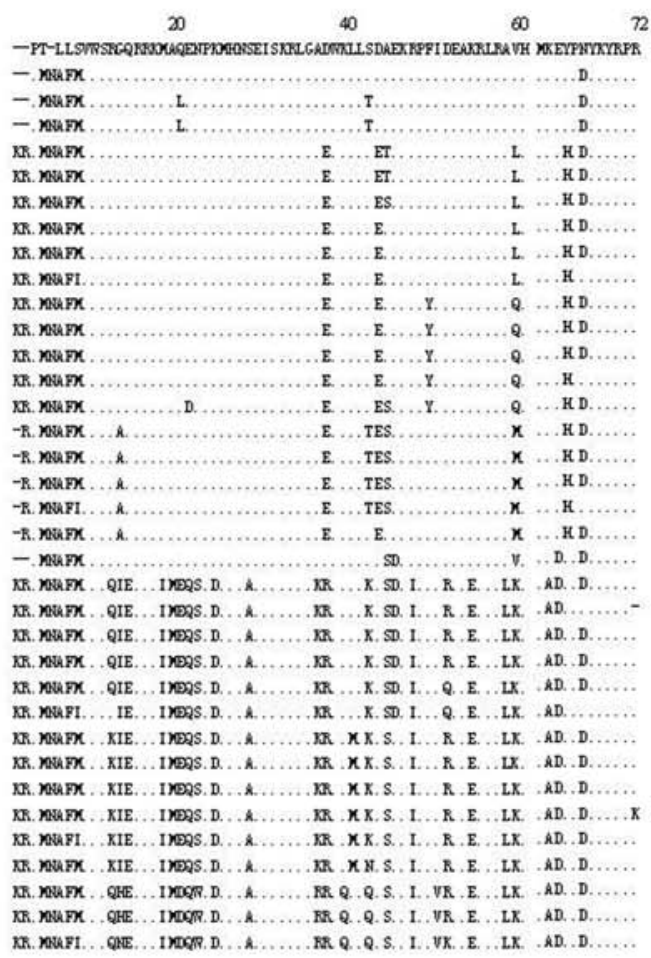

b

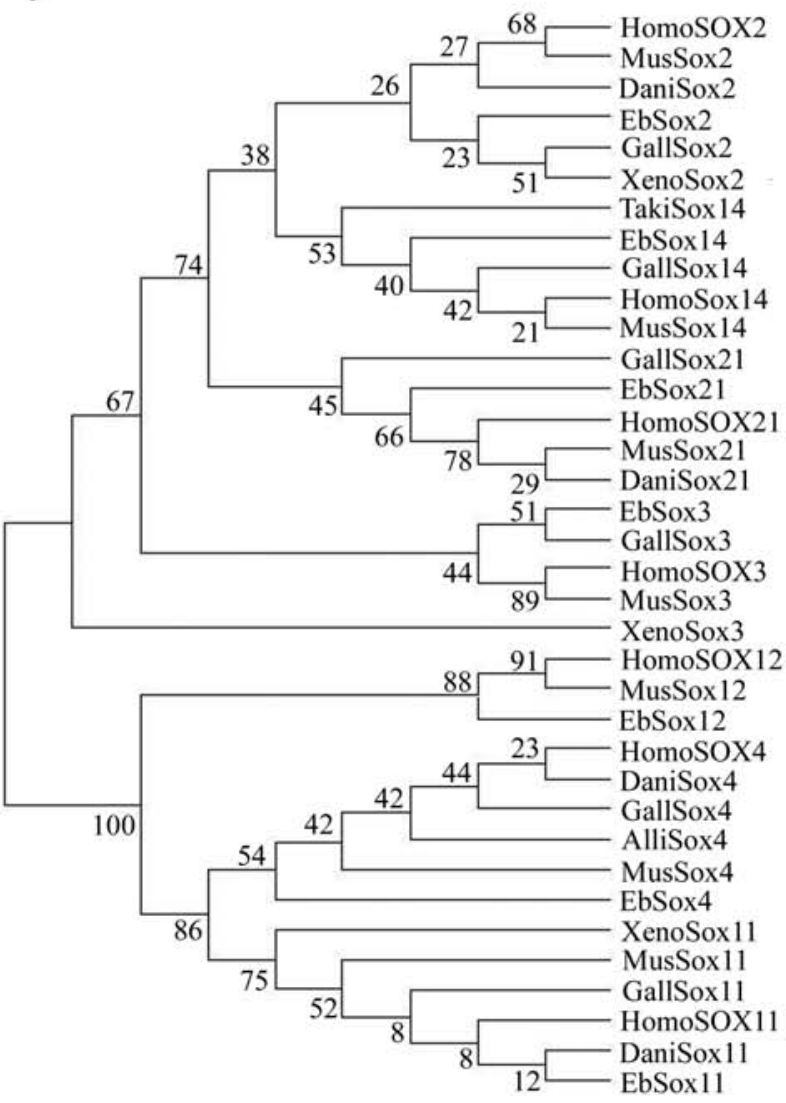

Figure 2 - Comparative analysis of Sox gene HMG-boxes in different species. (a) multiple alignment results; dots indicate identities with EbSox3; (b) phylogenetic analysis of the Sox gene family.
Table 1 - GenBank sequences searched in this study.

\begin{tabular}{|c|c|c|c|}
\hline Sequence & Accession number & Sequence & Accession number \\
\hline \multicolumn{2}{|l|}{ Homo sapiens } & \multicolumn{2}{|l|}{ Danio rerio } \\
\hline HomoSOX2 & NP 003097.1 & DaniSox2 & NP 998283.1 \\
\hline HomoSOX3 & NP 005625.2 & DaniSox4 & NP 998287.1 \\
\hline HomoSOX4 & NP 003098.1 & DaniSox 11 & NP 571411.1 \\
\hline HomoSOX11 & NP 003099.1 & DaniSox 21 & NP 001009888.1 \\
\hline HomoSOX12 & NP 008474.2 & & \\
\hline HomoSOX14 & NP 004180.1 & \multicolumn{2}{|c|}{ Xenopus laevis } \\
\hline \multirow[t]{2}{*}{ HomoSOX 21} & NP 009015.1 & XenoSox 2 & AAB62821.1 \\
\hline & & XenoSox 11 & AAH70707.1 \\
\hline \multicolumn{4}{|l|}{ Mus musculus } \\
\hline MusSox 2 & NP 035573.2 & \multicolumn{2}{|c|}{ Alligator sinensis } \\
\hline MusSox3 & NP 033263.1 & \multirow[t]{2}{*}{ AlliSox4 } & AA017690.1 \\
\hline MusSox4 & NP 033264.2 & & \\
\hline MusSox11 & NP 033260.4 & \multicolumn{2}{|c|}{ Takifugu rubripes } \\
\hline MusSox 12 & NP 035568.1 & TakiSox14 & AAQ18498.1 \\
\hline MusSox14 & XP 284529.3 & & \\
\hline MusSox 21 & NP 808421.1 & & \\
\hline \multicolumn{4}{|l|}{ Gallus gallus } \\
\hline GallSox2 & NP 990519.1 & & \\
\hline GallSox3 & NP 989526.1 & & \\
\hline GallSox4 & NP 989815.1 & & \\
\hline GallSox 11 & NP 990518.1 & & \\
\hline GallSox14 & NP 990092.1 & & \\
\hline GallSox21 & BAA77266.1 & & \\
\hline
\end{tabular}

entry (Laudet, et al., 1993). The occurrence of the sequence conservation among the Sox4 homologues in amniotes is interesting because the $S R Y$ gene shows rapid gene evolution in mammals which is possibly caused by Y-linked inheritance (Tucker and Lundrigan, 1993), although an ancient conserved function might also have restricted the divergence of Sox 4 gene homologues in amniotes. In fact, the amino acid sequences in the HMG box regions are highly conserved among different species including Eremias breuchleyi, but their functional conservation in sex determination and differentiation needs to be further studied.

\section{Acknowledgement}

This work is supported by the science foundation of the Key Laboratory of Biotic Environment and Ecological Safety in Anhui Provice, China. We thank two anonymous reviewers and the technical editor for critically reviewing of the manuscript.

\section{References}

Arsic N, Rajic T, Stanojcic S, Goodfellow PN and Stevanovic M (1998) Characterisation and mapping of the human SOX14 gene. Cytogenet Cell Genet 83:139-146. 
Bowles J, Schepers G and Koopman P (2000) Phylogeny of the Sox family of developmental transcription factors based on sequence and structural indicators. Dev Boil 227:239-255.

Collignon J, Sockanathan S, Hacker A, Cohen-Tannoudji M, Norris D, Rastan S, Stevanovic M, Goodfellow PN and Lovell-Badge R (1996) A comparison of the properties of Sox3, with Sry and two related genes, Sox 1 and Sox2. Development 122:509-520.

Foster JW, Dominguez-Steglich MA, Guioli S, Kwok C, Weller PA, Weissenbach J, Mansour S, Young ID, Goodfellow PN, Brook JD and Schafer AJ (1994) Campomelic dysplasia and autosomal sex reversal caused by mutations in an $S R Y$-related gene. Nature 372:525-530.

Hagiuda J, Hiraoka Y, Hasegawa M, Ogawa M and Aiso S (2003) A novel Xenopus laevis SRY-related gene, xSox33. Biochim Biophys Acta 1628:140-145.

Hargrave M, Karunaratne A, Cox L, Wood S, Koopmam P and Yamada T (2000) The HMG box transcription factor gene Sox14 marks a novel subset of ventral interneurons and is regulated by Sonic hedgehog. Dev Boil 219:142-153.

Hawkins JR (1994) Sex determination. Hum Mol Genet 3:14631470.

Kamachi Y, Sockanathan S, Liu Q, Breitman M, Lovell-Badge R and Kondoh H (1995) Involvement of SOX proteins in lens-specific activation of crystallin genes. EMBO J 14:3510-3519.

Laudet V, Stehelin D and Clevers H (1993) Ancestry and diversity of the HMG box superfamily. Nucleic Acids Res 21:24932501.

Li M, Pevny L, Lovell-Badge R and Smith A (1998) Generation of purified neural precursors from embryonic stem cells by lineage selection. Curr Biol 8:71-974.

Nagai K (2001) Molecular evolution of Sry and Sox gene. Gene 270:161-169.
Nie LW, Shan XN and Guo CW (1999) The PCR amplification and SSCP analysis of Sox gene in turtles (Platysternon megacephalum and Cistoclemmys flavomarginatus). Chin J Appl Environ Boil 5:378-381.

Pevny LH and Lovell-Badge R (1997) Sox genes find their feet. Curr Opin Genet Dov 7:338-344.

Pevny LH, Sockanathan S, Placzek M and Lovell-Badge R (1998) A role for $S O X 1$ in neural determination. Development 125:1967-78.

Rex M, Uwanogho DA, Orme A, Scotting PJ and Sharpe PT (1997) cSox21 exhibits a complex and dynamic pattern of transcription during embryonic development of the chick central nervous system. Mech Dev 66:39-53.

Sambrook J, Friston EF and Maniatis T (1989) Molecular Cloning, a Laboratory Mannual. Cold Spring Harbor Laboratory Press, New York.

Schilham MW, Oosterwegel MA, Moerer P, , de Boer PA, Verbeek S, Lamers WH, Kruisbeek AM, Cumano A and Clevers H (1996) Defects in cardiac outflow tract formation and pro-B-lymphocyte expansion in mice lacking Sox-4. Nature 380:711-714.

Tucker PK and Lundrigan BL (1993) Rapid evolution of the sex determining locus in old world mice and rats. Nature 364:715-717.

Uchikawa M, Kamachi Y and Kondoh H (1999) Two distinct subgroups of group B Sox genes for transcriptional activators and repressors: their expression during embryonic organogenesis of the chicken. Mech Dev 84:103-120.

Wagner T, Wirth J, Meyer J, Zabel B, Held M, Zimmer J, Pasantes J, Bricarelli FD, Keutel J, Hustert E, Wolf U, Tommerup N, Schempp W and Scherer G (1994) Autosomal sex reversal and campomelic dysplasia are caused by mutations in and around the SRY-related gene SOX9. Cell 79:1111-20.

Associate Editor: André Luiz Paranhos Perondini 